\title{
Distance education on dairy farming - its impact among learners
}

\author{
T Senthilkumar ${ }^{1}$, NK Sudeepkumar ${ }^{2}, M_{\text {Thirunavukkarasu }}^{3}$
}

${ }^{1}$ Directorate of Extension Education, TANUVAS, Chennai 51; ${ }^{2}$ University Publication Division, TANUVAS, Chennai 51; ${ }^{3}$ Deptartment of AH Statistics and Computer Applications, MVC, TANUVAS, Chennai 7, India

\begin{abstract}
A study was conducted to assess the impact of the distance education courses on dairy and goat farming on knowledge gained, skills obtained and economic benefits attained by the learners. The data was collected from 100 respondents who were selected randomly from 221 successful candidates during the period of 2000-01 to 2004-05. A majority of the respondents gained knowledge in credit/ insurance, housing systems followed by farm economics, clean milk production, calf rearing and feed and feeding methods. The respondents of all categories had increased their farm size (with percentage gain ranged between 59.38 and 75.07) and daily average milk yield (with percentage gain ranged between 48.34 and 66.17). Further the small, medium and large category farmers had gained additional income with per cent gain ranged from 73.38 to 122.26 . There was a highly significant gain in production and income in all categories of farmers with respect to farm size, milk yield, sale of milk, dung and animals and net change in the value of stock.
\end{abstract}

Key words: Distance course, dairy farming, impact, Knowledge, skills, economic benefits. Bangladesh Animal Husbandry Association. All rights reserved. Bang. J. Anim. Sci. 2012.40 (2): 136-140

\section{Introduction}

Globalization has effected tremendous change to the character and function of education worldwide. One of the most significant developments in the field of education during the last two decades has been the acceptance and growth of distance education through open learning systems across the world. In agriculture and animal husbandry education sector, the structural and regional need have created huge demand for knowledge and skill development among rural youth who belonged to the farming community (Mole and Tan 2004). Distance education in agriculture and allied subjects was initiated with the establishment of the first Open University in Andhra Pradesh, India in 1982 and with the establishment of Distance Education Council (DEC) under Statue 28, Section 5(2) of IGNOU Act 1985 under the Act of Parliament. Thus, distance education system needs to shoulder the responsibility of agricultural and allied education to some extent (Nimbalkar et al. 2004). Realizing these, the Tamil Nadu Veterinary and Animal Sciences University (TANUVAS) started offering correspondence courses on livestock farming since 1996. With the beneficiaries of these courses largely being livestock farmers and unemployed rural youth, the real impact of these courses on the learners has not been documented. Hence, this study was conducted to assess the impact of the distance education courses offered by TANUVAS on dairy farming for six months duration, in terms of knowledge gained, skills obtained and economic benefits attained by the learners.

\section{Materials and Methods}

The participants who underwent distance education courses on dairy farming conducted by TANUVAS during the period from 2000-01 to 2004-05 were considered as the respondents for the study. A total of 221 participants completed the distance course on dairy farming during the mentioned period, from whom 100 respondents were selected using proportionate random sampling as shown in Table 1.

Table1. Distribution of respondents in dairy farming course

\begin{tabular}{lccc}
\hline Year & $\begin{array}{l}\text { No. } \\
\text { candidates } \\
\text { enrolled }\end{array}$ & $\begin{array}{l}\text { No. } \\
\text { completed }\end{array}$ & $\begin{array}{l}\text { No. selected } \\
\text { for the study }\end{array}$ \\
\hline 2000-2001 & 98 & 47 & 21 \\
2001-2002 & 80 & 48 & 22 \\
$2002-2003$ & 111 & 64 & 29 \\
$2003-2004$ & 61 & 28 & 13 \\
$2004-2005$ & 61 & 34 & 15 \\
\hline Total & 411 & 221 & 100 \\
\hline
\end{tabular}

${ }^{*}$ Corresponding Author: drtskumar@yahoo.com 


\section{Data analysis}

Interview method was followed for data collection. An interview schedule incorporating items pertaining to objective of the study was constructed, pre-tested and finalized for data collection. The data were collected during the period 2007-09 and were coded, tabulated and necessary analytical techniques were used.

\section{Assessment of benefits accrued by learners}

The benefits accrued by the learners were measured in terms of gain in knowledge and skill, increase in production and productivity of farm enterprise performances among the learners of distance education courses, as below:

\section{Knowledge gain}

The procedure to measure percentage of knowledge gain followed by Chakarborty et al. (2000) was used. Accordingly, the test statements were prepared based on the course contents of dairy and goat farming courses and in consultation with the content developers of the respective courses. A set of 24 questions under nine major heads were selected for the dairy farming course. Each correct answer was given a score of 'one' and for the incorrect answer 'zero'. The total knowledge score of a respondent was worked out by summing up all the scores obtained for each item. Thus the maximum and minimum scores one could obtain ranged from ' 24 ' to ' 0 ' for the course on dairy farming.

Similarly for goat farming course, a set of 21 questions under eight major headings were selected. For each correct answer the respondents were given a score of 'one' and for the incorrect answer 'zero'. The total knowledge score of a respondent was worked out by summing up all the scores obtained for each item. Thus the maximum and minimum scores one could obtain ranged from ' 21 ' to ' 0 '.

To determine the knowledge gained as a result of distance learning, the knowledge test was implied to every respondent to find the pre-enrolment measurement and post-certification measurement at the time of interview. The difference between pre and post certification knowledge scores of the respondents indicated the gain in knowledge. The percentage gain in knowledge was calculated by adopting the following formula:

$\%$ gain in knowledge $=$

(Total score after certificaton- Total score before enrolment) $\times 100$ Maximum possible knowledge score

\section{Skill development}

Skill in the present study was defined as the ability of the learner to do / perform scientific practices in dairy / goat farming which they had learnt through the distance education course. To assess the skill gained through distance education programmes, a list of 15 items each for dairy and goat farming courses was prepared in consultation with distance education course providers and the respective study materials. These 15 items were subjected to the opinion of the extension functionaries to indicate the relative merit of the questions to be included in the final test. Thus, ten items each were included to measure the skill gained by the respondent. The response for skill test of each item was obtained on a five point continuum based on the frequency of skill utilized as score 3, 2. 1 and 0 for obtained new skill and improved skill over old skill, obtained new skill, improved skill over old skill and did not obtain any skill, respectively.

Weightage was arrived at by measuring the score value with number of respondents based on which total score and mean score was arrived at. The mean score thus arrived was classified and interpreted as obtained new skill and improved over old skill, obtained new skill, improved over old skill and did not provide any skill.

\section{Economic benefits}

The production performances were measured by the change in farm size, productivity in terms of daily average milk yield and body weight gain at pre-enrolment and post-certification stages. The difference if any was ascertained and the percentage gain worked out. The production level of the farmers was measured both at pre and post-certification stages. The level of income increase through the sale of milk, animals, dung and products, net change in value of stock, number of inseminations per conception, percentage of mortality, number of animals infected and number of animals insured were ascertained at pre-enrolment and postcertification stages. The actual difference was obtained and worked out in monetary value, along with percentage gain.

\section{Results and Discussion}

\section{Knowledge gained}

The respondents' increased level of knowledge based on percentage gain obtained by the individuals after undergoing the courses and the 


\section{Distance education on dairy farming}

results are presented in Table 2 . It could be observed that a majority gained knowledge in credit / insurance (96.50\%) and housing systems $(95.33 \%)$, followed by farm economics $(83.67 \%)$, clean milk production $(82.67 \%)$, calf rearing $(81.67 \%)$ and feed and feeding methods $(80.33 \%)$. However, there was lesser gain in areas such as disease control $(48 \%)$, breeding $(37 \%)$ and selection of breeds (31\%). This low level of gain might also be due to high level of knowledge at pre-enrolment stage itself and also due to their higher level of experience in dairy farm management.

\section{Skill developed}

The gain in the skill level of the respondents towards value addition of milk and detection of heat symptoms was two and above (Table 3), indicating that the learners obtained new skill in these two areas through this course. The others exhibited a score between one and two, implying that the respondents gained skill level which was 'improved over the old skill'. Only a few participants expressed that the course did not provide any skill, probably they had learnt these practices during prior trainings and or through their farm experience.

Jayasubramanian (1996) found that more than one-half $(59.50 \%)$ of the participants exposed to distance education programme through correspondence course had a knowledge gain of $85.70 \%$ as compared to pre-exposure stage. Biswas and Mythili (2004) revealed that nearly two-thirds $(62.90 \%)$ of the respondents of distance education gained knowledge about concept, methods and various specialized areas of distance education, while two-fifths (40.32\%) developed various skills, like designing and developing self-learning materials, writing tutor comments and evaluating assignment responses.

Table 2. Knowledge gained by the respondents of dairy farming course

\begin{tabular}{lcccc}
\hline Course contents & Pre-enrolment & Post-certification & Knowledge gain & Percent knowledge gain \\
\hline Credit/insurance & 7 & 200 & 193 & 96.50 \\
Housing & 14 & 300 & 286 & 95.33 \\
Farm economics & 38 & 289 & 251 & 83.67 \\
Clean milk production & 49 & 297 & 248 & 82.67 \\
Calf rearing & 49 & 294 & 245 & 81.67 \\
Feed and feeding & 55 & 296 & 241 & 80.33 \\
Disease control & 86 & 182 & 96 & 48.00 \\
Breeding & 106 & 180 & 74 & 37.00 \\
Selection of breeds & 178 & 271 & 93 & 31.00 \\
\hline
\end{tabular}

Table 3. Skill developed by the respondents of dairy farming course

\begin{tabular}{|c|c|c|c|c|c|c|}
\hline $\begin{array}{l}\text { Contents for skill } \\
\text { development }\end{array}$ & $\begin{array}{l}\text { Obtained new } \\
\text { and improved } \\
\text { over old skill }\end{array}$ & $\begin{array}{l}\text { Obtained } \\
\text { new skill }\end{array}$ & $\begin{array}{l}\text { I mproved } \\
\text { over old } \\
\text { skill }\end{array}$ & $\begin{array}{l}\text { Did not } \\
\text { provide } \\
\text { any skill }\end{array}$ & $\begin{array}{l}\text { Total } \\
\text { weightage } \\
\text { score }\end{array}$ & $\begin{array}{l}\text { Mean } \\
\text { score }\end{array}$ \\
\hline Value addition of milk & $17(56)$ & $65(130)$ & $18(18)$ & - & 204 & 2.04 \\
\hline $\begin{array}{l}\text { Detection of heat } \\
\text { symptoms }\end{array}$ & $5(15)$ & $11(22)$ & $82(164)$ & $2(0)$ & 201 & 2.01 \\
\hline $\begin{array}{l}\text { Preparing projects for } \\
\text { bank loan }\end{array}$ & $4(12$ & 87 (174) & $9(9)$ & - & 195 & 1.95 \\
\hline Feed formulation & $10(30)$ & $76(152)$ & $12(12)$ & $2(0)$ & 194 & 1.94 \\
\hline $\begin{array}{l}\text { Preparation of dairy } \\
\text { economics }\end{array}$ & $8(24)$ & $76(152)$ & $16(16)$ & - & 192 & 1.92 \\
\hline Dehorning in calves & $6(18)$ & $80(160)$ & $14(14)$ & - & 194 & 1.92 \\
\hline $\begin{array}{l}\text { Cutting of umbilical cord } \\
\text { and ligature in calves }\end{array}$ & $4(12)$ & $80(160)$ & $13(13)$ & $3(0)$ & 185 & 1.85 \\
\hline Identification of the age & $10(30)$ & $63(126)$ & $27(27)$ & - & 183 & 1.83 \\
\hline Milking methods & $5(15)$ & $30(60)$ & $64(64)$ & $1(0)$ & 139 & 1.39 \\
\hline Selection of dairy cow & $4(12)$ & $5(10)$ & $80(80)$ & $11(0)$ & 102 & 1.02 \\
\hline
\end{tabular}

(Figures in parentheses indicate weightage scores) 


\section{Economic benefits of the distance education on dairy farming}

The economic benefits obtained through increased production in terms of increase in farm size and milk yield of the respondents of dairy farming course are presented in Table 4 . It is evident that the respondents who maintained small herd size (<6.07 cattle units) increased their cattle units by 2.06 , while medium farmers (between 6.07 to 9.10 cattle units) increased farm size by 3.38 cattle and large farmers ( $>9.10$ cattle units) by 5.66 cattle. The percentage gain in flock size ranged between 59.38 and 75.07.

Table 4. Economic benefits through increased production

\begin{tabular}{|c|c|c|c|}
\hline $\begin{array}{l}\text { Type of } \\
\text { farmer }\end{array}$ & $\begin{array}{l}\text { Pre- } \\
\text { enrolment }\end{array}$ & $\begin{array}{l}\text { Post- } \\
\text { certification }\end{array}$ & Gain \\
\hline \multicolumn{4}{|c|}{ Average farm size (in cattle units) } \\
\hline $\begin{array}{l}\text { Small } \\
(<6.07)\end{array}$ & 2.750 & 4.808 & $\begin{array}{l}2.06 \\
(74.91)\end{array}$ \\
\hline $\begin{array}{l}\text { Medium } \\
(6.07-9.10)\end{array}$ & 5.692 & 9.077 & $\begin{array}{l}3.38 \\
(59.38)\end{array}$ \\
\hline $\begin{array}{l}\text { Large } \\
(>9.10)\end{array}$ & 7.540 & 13.200 & $\begin{array}{l}5.66 \\
(75.07)\end{array}$ \\
\hline \multicolumn{4}{|c|}{ Daily average milk yield (in litres) } \\
\hline $\begin{array}{l}\text { Small } \\
\text { farmers }\end{array}$ & 2.471 & 4.106 & $\begin{array}{l}1.64 \\
(66.17)\end{array}$ \\
\hline $\begin{array}{l}\text { Medium } \\
\text { farmers }\end{array}$ & 3.000 & 4.692 & $\begin{array}{l}1.69 \\
(56.40)\end{array}$ \\
\hline $\begin{array}{l}\text { Large } \\
\text { farmers }\end{array}$ & 3.043 & 4.514 & $\begin{array}{l}1.47 \\
(48.34)\end{array}$ \\
\hline
\end{tabular}

Figures in parentheses indicate percent gain

Further, the small farmer respondents gained a daily average milk yield of 1.64 litres, while medium farmers gained a milk yield of 1.69 litres and large farmers 1.47 litres, with the percentage gain ranging between 48.34 and 66.17 . That is, the knowledge and skill learnt through the course was reflected by the increase in farm size and daily average milk yield among all categories of the farmers, showing that the learners practiced what they learnt, which provided opportunities for additional income.

The economic benefits obtained through increased sale of milk, dung and animals, and improved net change in value of stock, number of inseminations per conception, mortality percentage, number of animals infected with diseases and number of animals insured are detailed in Table 5 .
Table 5. Economic benefits of the distance education on dairy farming

\begin{tabular}{|c|c|c|c|}
\hline $\begin{array}{l}\text { Type of } \\
\text { farmer }\end{array}$ & $\begin{array}{l}\text { Pre- } \\
\text { enrolment }\end{array}$ & $\begin{array}{l}\text { Post- } \\
\text { certification }\end{array}$ & Gain \\
\hline \multicolumn{4}{|c|}{ Number of inseminations/conception } \\
\hline Small & 2.5 & 2.0 & $0.5(20.00)$ \\
\hline Medium & 2.4 & 1.8 & $0.625 .00)$ \\
\hline Large & 2.6 & 1.7 & $0.934 .62)$ \\
\hline \multicolumn{4}{|c|}{ Number of animals infected with diseases } \\
\hline Small & 15 & 12 & $3(20.00)$ \\
\hline Medium & 7 & 5 & $2(28.57)$ \\
\hline Large & 18 & 9 & $9(50.00)$ \\
\hline \multicolumn{4}{|c|}{ Mortality in percentage } \\
\hline Small & 0 & 0 & 0 \\
\hline Medium & 0.03 & 0.02 & $0.01(33.33)$ \\
\hline Large & 0.03 & 0.02 & $0.01(33.33)$ \\
\hline \multicolumn{4}{|c|}{ Number of animals insured } \\
\hline Small & 0 & 2 & $2(200.00)$ \\
\hline Medium & 0 & 6 & $6(600.00)$ \\
\hline Large & 0 & 15 & $15(1500.00)$ \\
\hline \multicolumn{4}{|c|}{ Sale of milk (in rupees) } \\
\hline Small & 20152.21 & 44789.71 & $24637.50(122.26)$ \\
\hline Medium & 38914.62 & 67468.85 & $28554.23(73.38)$ \\
\hline Large & 48618.00 & 101647.29 & $53029.29(109.07)$ \\
\hline \multicolumn{4}{|c|}{ Sale of dung (in rupees) } \\
\hline Small & 1144.00 & 2000.00 & $856.00(74.83)$ \\
\hline Medium & 2276.92 & 3630.77 & $1353.85(59.46)$ \\
\hline Large & 3017.14 & 5280.00 & $2262.86(75.00)$ \\
\hline \multicolumn{4}{|c|}{ Sale of animals (in rupees) } \\
\hline Small & 541.38 & 1275.86 & 734.48(135.67) \\
\hline Medium & 3314.29 & 4357.14 & $1042.85(31.47)$ \\
\hline Large & 2431.03 & 3620.69 & $1189.66(48.94)$ \\
\hline \multicolumn{4}{|c|}{ Net change in value of available stock (in rupees) } \\
\hline Small & 25740.00 & 65840.00 & $40100.00(155.79)$ \\
\hline Medium & 51230.77 & 122307.69 & $71076.92(138.74)$ \\
\hline Large & 67885.71 & 179842.86 & $\begin{array}{l}111957.14 \\
(164.92)\end{array}$ \\
\hline
\end{tabular}

Figures in parentheses indicate percentage gain

The number of inseminations per conception among the small farmer category had decreased by 0.5 , while it was 0.6 and 0.9 among medium and large farmers, respectively. The improvement by reduction in number of animals infected by diseases was three, two and nine, respectively, in small, medium and large farmers. However, benefit in terms of reduced mortality was only negligible. But, the learners started insuring their animals after the course. The respondents in small farmer category gained an additional income of Rs.24,637.50 per annum through sale of milk, while medium and large farmers gained Rs.28,554.23 and Rs.53,029.29 per annum, respectively. The per cent gain ranged from 73.38 (medium farmer) to 122.26 (small farmer). The increase in net income per household per annum through sale of dung was found to be Rs. 856, Rs. 1,353.85 and Rs.2,262.86 in small, medium and large farmers, with the per cent gain ranging between 59.46 and 75.00 . 


\section{Distance education on dairy farming}

Table 6. Effectiveness of distance education program in terms of economic benefits obtained by the respondents

\begin{tabular}{lllllll}
\hline \multirow{2}{*}{ Variables } & \multicolumn{3}{c}{ Mean Gain } & \multicolumn{3}{c}{ 't' Value } \\
\cline { 2 - 7 } & $\begin{array}{l}\text { Small } \\
\text { farmers }\end{array}$ & $\begin{array}{l}\text { Medium } \\
\text { farmers }\end{array}$ & $\begin{array}{l}\text { Large } \\
\text { farmers }\end{array}$ & $\begin{array}{l}\text { Small } \\
\text { farmers }\end{array}$ & $\begin{array}{l}\text { Medium } \\
\text { farmers }\end{array}$ & $\begin{array}{l}\text { Large } \\
\text { farmers }\end{array}$ \\
\hline Farm size (in cattle units) & 2.06 & 3.38 & 5.66 & $9.92^{* *}$ & $12.70^{* *}$ & $5.22^{* *}$ \\
Average milk yield (in litres) & 1.64 & 1.69 & 1.48 & $9.13^{* *}$ & $9.68^{* *}$ & $12.32^{* *}$ \\
$\begin{array}{l}\text { Sale of milk (in Rs.) } \\
\text { Sale of dung (in Rs.) }\end{array}$ & 24637.50 & 28554.23 & 53029.29 & $11.28^{* *}$ & $10.82^{* *}$ & $5.67^{* *}$ \\
$\begin{array}{l}\text { Sale of animals (in Rs.) } \\
\text { Net change in the value of }\end{array}$ & $\mathbf{8 5 6 . 0 0}$ & $\mathbf{1 3 5 3 . 8 5}$ & 2262.86 & $9.92^{* *}$ & $12.70^{* *}$ & $5.22^{* *}$ \\
available stock (in Rs.) & $40,100.00$ & 71076.92 & 111957.14 & $14.56^{* *}$ & $14.36^{* *}$ & $6.87^{* *}$ \\
\hline
\end{tabular}

**, significant at $1 \%$ level

The incremental net income obtained through sale of animals per household per annum was Rs. 734.48 (135.67\% gain), Rs. 1042.85 (31.47\% gain) and Rs. 1189.66 (48.94\% gain) in small, medium and large farmer categories, respectively. Further, the net change in the value of stock increased by Rs.40,100 (155.79\% gain), Rs. $\quad 71,076.92 \quad(138.74 \%$ gain) and Rs. $1,11,957.14$. (164.92\% gain) in small, medium and large farmer categories, respectively. In all, there was a remarkable economic gain earned by the learners of dairy farming course, both in terms of absolute value and percentage gain.

These results were further subjected to statistical analysis to find out the effectiveness of distance education programs with regard to economic benefits. Paired ' $\mathrm{t}$ ' test was used to find whether there was any significant gain in production and income from pre-enrolment to post-certification stage due to the knowledge and skill gained through course and applied. The results of the test are given in Table 6 .

There was a highly significant gain in production and income in all categories of farmers with respect to farm size, milk yield, sale of milk, dung and animals and net change in the value of stock. However, the gain earned in other attributes number of inseminations per conception, percentage of mortality, number of animals infected with disease and number of animals insured was not significant.

\section{Conclusions}

The study revealed that the learners of distance education could translate knowledge into practice which resulted in production and productivity gain in dairy farming. The benefits accrued by the learners of the dairy farming distance course in terms of knowledge and skill appear to be significant. Also the economic gains were found to be highly significant statistically. It implies that entrepreneurs and newcomers who like to venture livestock farming can learn effectively through enrolling in such courses.

\section{References}

Biswas PK and G Mythili (2004). Impact of distance education programmes of IGNOU on personal and career development of distance learners. Ind. J. Open Learning. 13: 79-86.

Chakarborty R, HN Katoty and A Borgohain (2000). Effect of some important personal and socio-economic factors on gain of knowledge through radio. Ind. J. Social Res. 41: 169-175.

Jayasubramanian B (1996). Impact of distance education programme of TNAU through correspondence course: A diagnostic analysis. Unpublished M.Sc. (Ag.) Thesis, TNAU, Coimbatore.

Mole KH and J Tan (2004). Globalization and marketization of education. Available online www.col.org.

Nimbalkar SA, VD Patil and PO Ingle (2004). Distance agricultural education: Perspectives in agricultural development in India. Available online www.col.org. 